\title{
ANALISIS PEMAHAMAN SISWA TERHADAP MATERI PENDIDIKAN PANCASILA DAN KEWARGANEGARAAN DENGAN MENGGUNAKAN ALAT PERAGA DALAM PROSES PEMBELAJARAN
}

\author{
*Tamarli, **Akhyar \\ *Tamarli adalah Staf Pengajar Universitas Abulyatama Aceh \\ Email : tamarli326@gmail.com \\ *Akhyar adalah Staf Pengajar Universitas Abulyatama Aceh \\ Email : akhyar293@gmail.com
}

\begin{abstract}
Abstrak
Keberhasilan proses pembelajaran sangat ditentukan oleh pendukung proses pembelajaran tersebut, Salah satu pendukung keberhasilan proses pembelajaran di sekolah dengan menggunakan alat peraga. Pembelajaran dengan penggunaan alat peraga menjadi salah satu cara yang sering diterapkan guru dalam kegiatan pembelajaran Pendidikan Pancasila dan Kewarganegaraan dalam meningkatkan pemahaman siswa terhadap materi yang disampaikan guru. Namun demikian masih ada siswa yang kurang memahami materi Pendidikan Pancasila dan Kewarganegaraan, walaupun dalam pelaksanaan pembelajaran menggunakan alat peraga. Hal inilah yang menjadi latar belakang peneliti melakukan penelitian. Tujuan penelitian ini adalah untuk mengetahui tingkat pemahaman siswa terhadap materi Pendidikan Pancasila dan Kewarganegaraan yang diajarkan dengan menggunakan alat peraga. Metode penelitian ini adalah penelitian kualitatif dan istrumen yang digunakan tes, interview dan wawancara. Obyek penelitian ini adalah siswa kelas XI-3 SMA Negeri 8 Banda Aceh yang berjumlah 40 orang.Tekenik analisis data dilakukan secara deskriptif dengan persentase. Hasil penelitian menunjukkan bahwa tingkat pemahaman siswa terhadap materi Pendidikan Pancasila dan Kewarganegaraan pada kategori memahami yaitu pada kategori sangat memahami sebanyak 35\% (14) orang siswa dan pada kategori memahami sebanyak 65\% (26) orang siswa kelas XI-3 SMA Negeri 8 Banda Aceh.
\end{abstract}

Kata kunci : : Pemahaman, alat peraga dan Proses pembelajaran

\section{PENDAHULUAN}

Pendidikan adalah usaha yang dilakukan secara sadar untuk mengembangkan kopetensi manusia baik pengetahuan, sikap dan ketrampilan sehingga menjadi manusia yang utuh. Hal ini sesuai dengan tujuan pendidikan yang telah dirumuskan dalam UU No. 20 tahun 2003, bahwa "Pendidikan nasional berfungsi mengembangkan kemampuan dan membentuk watak serta peradaban bangsa yang bermartabat dalam rangka mencerdaskan kehidupan bangsa, bertujuan untuk berkembangnya potensi peserta didik agar menjadi manusia yang bertakwa kepada Tuhan YME, berakhlak mulia, sehat, berilmu, cakap, kreatif, 
mandiri dan menjadi warga negara yang demokratis serta bertanggung jawab". dalam UU No. 20 tahun 2003 menunjukkan bahwa tugas pendidik terutama guru sangatlah berat.

Pendidikan yang berlangsung di sekolah juga merupakan suatu usaha yang dilakukan oleh guru untuk menanamkan sejumlah ilmu pengetahuan yang dimilikinya kepada anak didik, sehingga mereka menjadi manusia yang penuh tanggung jawab, baik terhadap dirinya sendiri maupun terhadap bangsa dan Negara. Sekolah sebagai tempat berlangsungnya proses pendidikan, memerlukan berbagai factor penunjang dan fasilitas lain yang dapat mempermudah pencapaian tujuan akhir pendidikan baik pengetahuan, sikap dan ketrampilan..

Guru sebagai salah satu komponen yang sangat menentukan keberhasilan siswa di sekolah. Jika seorang seorang guru atau pendidik tidak berhasil mengembangkan potensi peserta didik baik potensi pengetahuan, sikap dan ketrampilan maka bangsa dan negara itu tidak akan berkembang dan maju, sebaliknya jika guru atau pendidik berhasil mengembangkan potensi peserta didik, maka terciptalah manusia yang cerdas, terampil, dan berkualitas. Sesuai dengan iasi pendidikan nasional yang terdapat dalam UU Sitem Pendidikan Nasional Nomor 20 tahun 2003 yang menyatakan “ pendidikan yang berdasarkan pancasila dan Undang-Undang Dasar Republik Indonesia Tahun 1945 yang berakar pada nilai-nilai agama, kebudayaan nasional Indonesia dan tanggap terhadap perubahan zaman.

Pendidikan Pancasila dan Kewarganegaraan adalah satu mata pelajaran adalah mata pelajaran yang memfokuskan pada pembentukan diri yang beragam dari segi agama, sosiokultural, bahasa, usia, suku bangsa untuk menjadi warga negara yang cerdas, terampil, dan berkarakter yang dilandasi oleh Pancasila dan UUD 1945”.

Dengan demikian peranan guru Pendidikan Pancasila dan Kewarganegaraan sangat menentukan tercapainya tujuan mata pelajaran Pancasila dan Kewarganegaraan. Menurut Sanjaya (2006 : 19), peran guru adalah: "Sebagai sumber belajar, fasilitator, pengelola, demonstrator, pembimbing, dan evaluator". Sebagai motivator guru harus mampu membangkitkan motivasi siswa agar aktivitas siswa dalam proses pembelajaran berhasil dengan baik.

Oleh karena itu guru Pendidikan Pancasila dan Kewarganegaraan harus mampu menciptakan proses pembelajaran yang bermutu dengan menggunakan berbagai alat peraga, media strategi, metode dan model pembelajaran, yang dapat mengembangkan potensi siswa di sekolah. Memenuhi tujuan tersebut di atas para pendidikan berkewajiban menanamkan 
ilmu pengetahuan yang dimilikinya kepada anak didik sesuai dengan tuntutan kurikulum yang telah ditetapkan pemerintah sehingga terwujudlah kecerdasan bangsa secara menyeluruh. Dengan perkataan lain anak didik dihadapkan dengan berbagai ilmu pengetahuan yang diberikan oleh gurunya. Seorang guru dalam menyampaikan pelajaran akan mempergunakan berbagai macam cara mengajar untuk mencapai tujuan pelajaran yang telah digariskan dalam tujuan instruksional. Adanya bermacam-macam alat peraga mengajar disebabkan oleh berbagai komponen seperti komponen tujuan pengajaran, fasilitas yang tersedia, situasi kelas dan lingkungan yang beraneka ragam, anak didik serta kepribadian guru itu sendiri. Pengaruh dari berbagai komponen tersebut di atas guru harus menyesuaikan alat peraga mengajar, sehingga pengajaran dapat berhasil dengan baik sesuai dengan tujuan yang diharapkan.

Tercapainya tujuan pendidikan sangat tergantung pada bagaimana proses belajar mengajar itu berlangsung. Oleh sebab itu, dalam upaya meningkatkan pemahaman siswa terhadap sesuatu konsep. Guru dalam mengelola kegiatan belajar belajar harus memperhatikan tingkat intelektual siswa, serta alat peraga yang sesuai agar dapat meningkatkan keterampilan berpikir siswa dan dapat memberi contoh yang konkrit sehingga siswa mudah memahami dan tertarik untuk mempelajari mata pelajaran yang diajarkan.

Mengingat betapa pentingnya alat peraga dalam proses belajar mengajar pada umumnya dan mata pelajaran Pendidikan Pancasila dan kewarganegaraan khususnya, maka pemakaian alat peraga yang baik dan sesuai dengan materi yang diajarkan adalah mutlak dilakukan oleh guru atau pendidik seperti yang dikemukakan oleh pendapat para ahli, menurut Juprianda (2015: 35 ) bahwa penggunaan alat peraga mampu memberi kesan yang lebih dalam dan bermakna bagi siswa shingga dapat menumbuhkan sikap positif bagi proses dan hasil belajar.

Menggunakan alat peraga dalam pembelajaran sangat efektif, sebab membantu para siswa untuk mencari jawaban dengan usaha sendiri berdasarkan fakta-fakta atau data yang ada. Karena dengan menggunakan alat peraga dalam proses pembelajaran lebih memudahkan siswa memahami pelajaran dari pada tanpa menggunakan alat peraga. Hal ini sesuai dengan pendapat Sukayati (2003 :2) bahwa alat peraga merupakan alat bantu atau sarana yang digunakan oleh guru untuk menunjang proses belajar mengajar.

Menurut kurikulum SMA, yaitu suatu hasil pendidikan dapat dianggap tinggi mutunya apabila kemampuan pengetahuan dan sikap yang dimiliki para lulusan berguna bagi 
perkembangan selanjutnya. Baik lembaga pendidikan yang tinggi maupun dimasyarakat kerja, sedang mutu sendiri baru mungkin kita capai, jika proses belajar yang kita selenggarakan benar-benar efektif dan fungsional bagi tercapainya pengetahuan, kemampuan sikap yang dimaksud.

Penggunaan alat peraga mata pelajaran Pendidikan Pancasila dan Kewarganegaraan bukanlah masalah yang baru, karena setiap proses pengajaran yang dilakukan oleh guru mempunyai tujuan masing-masing, untuk terlaksananya proses belajar mengajar dengan baik, penggunaan-penggunaan alat peraga sangat diperlukan, karena dengan penggunaan alat peraga tersebut akan dapat menimbulkan minat belajar siswa-siswa. Dengan demikian, seorang guru harus mampu menggunakan alat peraga dalam pengajaran Pendidikan Pancasila dan Kewarganegaraan dengan baik, agar tercapai hasil yang diharapkan.

Penggunaan alat peraga dalam proses pembelanjaran Pendidikan Pancasila dan Kewarganegaraan di sekolah diharapkan akan membawa keuntungan yang besar bagi anak didik dalam mempelajari Pendidikan Pancasila dan Kewarganegaraan. Ingatan anak didik akan bertahan lama terhadap apa yang dipelajarinya, karena mereka telah bertukar pendapat melaluiproses belajar mengajar dengan menggunakan alat peraga.

Penggunaan alat peraga dalam pembelajaran, guru dapat memilih sesuai dengan pokok bahasan yang akan disampaikan suasana kelas menjadi hidup sehingga dapat membangkitkan semangat belajar siswa. Karena fungsi utama alat peraga untuk menurunkan keabstrakan dari konsep, tersebut, agar siswa mampu menangkap arti sebenarnya dari konsep tersebut. Dengan melihat meraba, memanipulasi obyek/alat peraga maka siswa akan mempunyai pengalaman-pengalaman nyata dalam kehidupan tentang arti dari konsep materi.

Pengajaran Pendidikan Pancasila dan Kewarganegaraan memerlukan penggunaan alat peraga yang cocok dan sesuai dengan kurikulum serta kemampuan siswa, karena hakekat Pendidikan Pancasila dan Kewarganegaraan adalah mata pelajaran yang digunakan sebagai wahana untuk mengembangkan dan melestarikan nilai luhur dan moral yang berakar pada budaya bangsa Indonesia yang diharapkan dapat diwujudkan dalam bentuk perilaku dalam kehidupan sehari-hari siswa, baik sebagai individu maupun sebagai anggota masyarakat, dan makhluk ciptaan Tuhan Yang Maha Esa.

Penggunaan alat peraga mampu memberi kesan yang lebih dalam dan lebih bermakna bagi siswa. Bahwa dalam proses belajar mengajar sehari-hari siswa tidak terlepas dari suatu 
masalah, termasuk dalam menggunakan alat peraga, perbedaan setiap individu menghasilkan tingkat pemahaman yang berbeda dalam pembelajaran yang menggunakan alat peraga. Ada siswa yang memiliki tingkat pemahaman tinggi, ada siswa yang memiliki pemahaman yang rendah dan ada yang memilkiki tingkat pemahaman yang sedang.

Menurut Benjamin S. Bloom (dalam Anas Sudijono, 2011 : 50) bahwa pemahaman adalah kemampuan seseorang untuk mengerti atau memahami sesuatu setelah sesuatu itu diketahui dan diingat. Artinya memahami adalah mengerti tentang sesuatu dan dapat melihatnya dari berbagai segi.

Kenyataan yang terjadi disekolah masih ditemukan bahwa guru Pendidikan Pancasila dan Kewarganegaran dalam proses pembelajaran sering menggunakan alat peraga untuk meningkatkan pemahaman siswa terhadap terhadap materi yang disajikan. Alat peraga yang dimiliki Sekolah Menengah Atas Negeri 8 Banda Aceh mamadai, sehingga pembelajaran berjalan dengan lancar. Namun masih terdapat siswa belum dapat meningkat pamahaman terhadap konsep materi yang diajarkan melalui penggunaan alat peraga, sehingga pengembangan potensi siswa tidak optimal yang mempengaruhi prestasi belajar siswa yang rendah, terutama dalam pemahaman konsep materi Pendidikan Pancasila dan Kewarganegaraan.

\section{Alat Peraga dalam Proses Pembelajaran}

Alat peraga adalah alat-alat yang digunakan oleh pendidik dalam menyampaikan bahan pengajaran. Alat peraga ini berfungsi untuk membantu dan meragakan sesuatu dalam proses pendidikan dan pengajaran. Menurut A. Samana (2001) bahwa alat bantu pendidikan adalah alat-alat yang digunakan oleh pendidik dalam menyampaikan bahan pengajaran. Alat bantu ini lebih sering disebut sebagai alat peraga karena berfungsi untuk membantu dan meragakan sesuatu dalam proses pendidikan dan pengajaran. Sedangkan menurut Azhar Arsyad (1997) bahwa alat peraga yaitu alat bantu pada proses belajar baik di dalam maupun di luar kelas. Alat peraga atau media pedidikan memiliki pengertian fisik yang dewasa ini dikenal sebagai hardware (perangkat keras), yaitu suatu benda yang dapat dilihat, didengar atau diraba dengan panca indera. Alat peraga atau media pendidikan memiliki pengertian non fisik yang dikenal sebagai software (perangkat lunak) yaitu kandungan pesan yang terdapat dalam perangkat keras yang merupakan isi yang disampaikan kepada siswa di sekolah..

Jurnal Serambi Ilmu. p-ISSN 1693-4849, e-ISSN 2549-2306 Journal of Scientific Information and Educational Creativity 
Pembelajaran sering digunakan untuk menunjukkan kegiatan antara guru dan siswa serta sumber belajar pada lingkungan belajar tertentu yang mengakibatkan terjadinya perubahan tingkah laku kearah yang lebih baik. Selain itu, proses pembelajaran juga bertujuan agar siswa berhasil mengetahui materi sesuai dengan indikator yang telah ditetapkan (Kunandar, 2008:287 dan Setyowati, 2013:1). Udin (2007:19) dan Kuswadi (2011: 14), menyatakan pembelajaran adalah suatu kombinasi yang tersusun meliputi unsurunsurmanusiawi, material, fasilitas perlengkapan dan prosedur, yang salingmempengaruhi untuk mencapai tujuan pembelajaran. Hal ini sependapat dengan Harefa (2005: 59), pengajaran itu hanya menyangkut soal teori dan belajar tentang diri, sedangkan pembelajaran itu sepenuhnya soal potensi dan belajar menj

adi dirinya sendiri. Berdasarkan uraian di atas dapat disimpulkan bahwa belajar adalah suatu aktivitas mencari tahu sesuatu yang belum diketahui sehingga mengakibatkan perubahan tingkah laku pada diri seseorang, sedangkan pembelajaran merupakan proses interaksi antara peserta didik dengan lingkungannya sehingga terjadi perubahan tingkah laku kearah yang lebih baik. Proses interaksi antara guru dan siswa terjadi lebih baik, bila guru dalam proses pembelajaran menggunakan alat peraga pembelajaran karena alat peraga. Alat peraga adalah alat-alat yang digunakan oleh pendidik dalam menyampaikan materi pengajaran, baik di dalam kelas maupun di luar kelas. Yang berfungsi membantu dan meragakan sesuatu dalam proses belajar mengajar seshingga siswa lebih mudah memahami bahan ajar yang disampaikan guru. Oleh karena itu fungsi alat peraga dapat meningkatkan prestasi belajar siswa termasuk dalam meningkatkan prestasi belajar Pendidikan Pancasila dan Kewarganegaraan

Hasil belajar merupakan tolak ukur yang utama untuk mengetahui keberhasilan belajar seseorang. Seorang yang prestasinya tinggi dapat dikatakan bahwa ia telah berhasil dalam belajar (Winkel, 2004:38). Menurut Anni (2004:4), hasil belajar merupakan perubahan perilaku yang diperoleh siswa setelah mengalami aktivitas belajar. Sedangkan Abdurrahman (2009:37) dan Hafnida (2012:8) mengemukakan hasil belajar adalah kemampuan seseorang setelah menerima pengalaman belajarnya dalam mencapai tujuan pembelajaran. Dari hasil belajar terjadi perubahan tingkah laku dan terbentuk pribadi individu yang selalu ingin mencapai hasil yang lebih baik lagi sehingga akan mengubah cara berpikir serta menghasilkan perilaku kerja yang baik. Hasil belajar tidak hanya ditentukan dari kemampuan belajar, tetapi juga melalui model pembelajaran yang diterapkan dalam proses pembelajaran.

Jurnal Serambi Ilmu. p-ISSN 1693-4849, e-ISSN 2549-2306 Journal of Scientific Information and Educational Creativity 
Dengan demikian hasil belajar adalah perubahan tingkah laku yang terjadi pada peserta didik setelah mengalami proses belajar.

Keberhasilan belajar dipengaruhi oleh dua faktor utama yaitu:Faktor internal dan faktor eksternal. Faktor internalmerupakan faktor yang berasal dari diri individu. Faktor inimeliputi: a) faktor fisiologis, yang menyangkut keadaan jasmani atau fisik individuyang dapat dibedakan menjadi dua macam yaitu keadaan jasmani pada umumnya dan keadaan jasmani tertentu terutama panca indera. Kondisi jasmani yang menandaitingkat kebugaran organ-organtubuh dan sendi-sendinya dapat mempengaruhisemangat dan intensitas siswa dalam mengikuti pelajaran. Kondisi organ-organkhusus siswa seperti tingkat kesehatan indera penglihatan dan pendengaran jugasangat mempengaruhi kemampuan siswa dalam menyerap informasi danpengetahuan yang disajikan di kelas; b) faktor psikologis yang meliputi tingkatkecerdasan, sikap, bakat, minat dan motivasi.

Faktor eksternal merupakan faktor dari luar individu. Faktor ini meliputi: a)faktor sosial yang menyangkut hubungan antar manusia yang terjadi dalam berbagai situasisosial, meliputi lingkungan keluarga, sekolah, teman, dan masyarakat padaumumnya; b) faktor nonsosial yaitu faktor-faktor lingkungan yang bukan sosial seperti lingkungan alam fisik misalnya keadaan rumah, ruang belajar, fasilitasbelajar, buku-buku, dan sebagainya. Faktorfaktor tersebut harus diatur sedemikian rupa sehingga proses belajar dapat memperoleh hasil yang maksimal. Waktu yang lama bukanlah jaminan prestasibelajar yang dihasikan akan maksimal, sebab bukan waktu yang penting dalambelajar melainkan kesiapan sistem memori siswa dalam menyerap, mengelola danmenyimpan informasi dan pengetahuan yang dipelajari siswa (Djamarah, 2008: 176, Enco, 2004: 191 dan Suryabrata, 2012: 233).Jadi faktor internal yangmempengaruhi belajar adalah faktor fisiologi dan faktor psikologi, sedangkan faktor eksternal yang mempengaruhi belajar adalah faktor sosial dan non-sosial

Upaya peningkatan kualitas pendidikan atau hasil belajar ditempuh melalui peningkatan sarana dan prasarana, perubahan kurikulum dan proses belajar mengajar, peningkatan kualitas guru, penyempurnaan sistem penilaian, pembaharuan metode dan model-model pembelajaran, alat peraga pembelajaran serta usaha-usaha lain yang tercakup dalam komponen pendidikan. Dalam rangka meningkathan hasil belajar siswa dalam hal ini peningkatan pemahaman siswa terhadap materi Pendidikan Pancasila dan Kewarganegaraan, guru dituntut untuk berperan sebagai seseorang yang merancang pembelajaran salah satunya merancang alat peraga dalam poroses pembelajaran. Agar suasana dalam kelas menjadi 
menyenangkan maka guru sebagai pendidik harus bisa memilih alat peraga pembelajaran yang tepat bagi peserta didiknya sehingga dapat meningkatkan keberhasilan siswa dalam belajar sekaligus sebagai indikator peningkatan kualitas pendidikan. .

Dari uraian di atas dapat disimpulkan bahwa dalam rangka meningkatan pemahamaman siswa terhadap materi Pendidikan Pancasila dan Kewarganegaraan diperlukan peran guru kreatif yang dapat membuat proses pembelajaran menjadi lebih menyenangkan bagi peserta didik. Misalnya, dengan penggunaan alat peraga pembelajaran yang tepat agar siswa dapat memperoleh kesempatan berinteraksi satu sama lain sehingga memperoleh hasil belajar yang optimal.

\section{METODE PENELITIAN}

\section{Tempat dan Obyek penelitian}

Penelitian ini dilakukan di SMA Negeri 8 Banda Aceh, sedangkan waktu penelitian pada semester genap tahun ajaran 2018/2019. Dalam penelitian ini yang menjadi obyek penelitiannya adalah seluruh siswa kelas XI-3 di SMA Negeri 8 Banda Aceh. Berdasarkan observasi awal dan informasi yang penulis dapat dari hasil wawancara awal dengan kepala sekolah Kepala Sekolah SMA Negeri 8 Banda Aceh siswa kelas XI-3 SMA Negeri 8 Banda Aceh tahun ajaran 2018/2019 seluruhnya berjumlah 40 orang siswa dengan perincian 18 orang siswa laki-laki dan 22 orang siswa perempuan, ke 40 orang siswa tersebut adalah populasi dalam penelitian ini. Dalam penelitian ini karena jumlah populasinya sedikit (terbatas) sehingga tidak memungkinkan untuk menggunakan sampel, sehingga peneliti mengambil jumlah sampel sama dengan jumlah populasi atau disebut dengan sensus yaitu sampel yang diambil dari penelitian ini adalah 40 orang atau satu kelas saja yaitu kelas XI SMA Negeri 8 Banda Aceh.

\section{Pendekatan dan Jenis Penelitian}

Menurut Sugiyono (2012), "Metode Penelitian pada dasarnya merupakan cara ilmiah untuk mendapatkan data yang valid dengan tujuan dapat ditemukan, dibuktikan, dan dikembangkan suatu pengetahuan sehingga pada gilirannya dapat digunakan untuk memahami, memecahkan dan mengantisipasi masalah".

Jurnal Serambi Ilmu. p-ISSN 1693-4849, e-ISSN 2549-2306 Journal of Scientific Information and Educational Creativity 
Sedangkan penelitian ini penulis menggunakan metode penelitian deskriptif dengan pendekatan kualitatif. "Metode Deskriptif adalah metode yang digunakan untuk menggambarkan atau menganalisis suatu hasil penelitian tetapi tidak digunakan untuk membuat kesimpulan yang lebih jelas" (Sugiyono, 2012).

Dari pengertian diatas dapat disimpulkan bahwa metode deskriptif merupakan metode penelitian untuk membuat gambaran mengenai situasi atau kejadian yang ada, sehingga metode ini harus diadakan akumulasi data. Adapun yang ingin dideskripsikan dalam penelitian ini adalah sejauh mana tingkat pemahaman siswa terhadap konsep materi Pendidikan Pancasila dan Kewarganegaraan yang diajarkan dengan menggunakan alat peraga. Data yang akan diperoleh dalam penelitian ini dikumpulkan dengan menggunakan tes. Instrumen tes adalah dengan soal pemahaman konsep materi Pendidikan Pancasila dan Kewarganegaraan.

\section{Teknik Pengumpulan Data}

Teknik pengumpulan data adalah cara yang digunakan peneliti untuk mendapat kan data yang dibutuhkan dalam penelitian. Hal ini sesuai yang dikemukalan oleh Arikunto (2006) seautu penelitian harus menggunakan teknik pengumpulan data karena teknik pengumpulan adalah adalah cara yang digunakan peneliti dalam peroleh data penelitian.

Menggunakan teknik pengumpulan data, peneliti memelukan instrument penelitian seperti tes ( pemberian soal), interview dan lembaran angket yang digunakan sebagai alat bantu agar pekerjaan mengumpul data lebih mudah. Instrument merupakan suatu alat atau fasilitas yang biasanya digunakan oleh peneliti dalam mengumpulkan data agar penelitiannya lebih mudah dan hasilnya lebih baik. Dalam arti cermat, lengkap, dan sistematis, sehingga lebih mudah untuk diolah ( Arikunto, 2006:160). Penelitian ini mengguanakn instrument berupa tes, interview, dan pemberian angket. Berikut diuraikan instrumen pengumpulan data yang digunakan dalam penelitian ini.

\section{a. Tes}

Menurut Arikunto (2002:127) tes adalah serentetan pertanyaan atau latihan atau alat yang digunakan untuk mengukur keterampilan, pengetahuan intelegensi, kemampuan atau bakat

Jurnal Serambi Ilmu. p-ISSN 1693-4849, e-ISSN 2549-2306 Journal of Scientific Information and Educational Creativity 
yang dimiliki individu atau kelompok.Instrument untuk metode tes adalah dengan tes.soal pemahaman. Dalam proses pembuatan tes atau soal pemahaman dibantu oleh dosen pembimbing skripsi, kisi-kisi instrument dibuat berdasarkan tiga indicator pemahaman belajar siswa yaitu: Menerjemahkan (translation), menafsirkan (interpretation), mengekstrapolasi (extrapolation). Berikut kisi-kisi pembuatan soal pemahaman siswa.

Tabel 1 Kisi-kisi Pembuatan Soal Pemahaman Siswa.

\begin{tabular}{|c|c|c|c|c|c|}
\hline No & Tingkatan & Indikator & $\begin{array}{l}\text { Nomor } \\
\text { Soal }\end{array}$ & Skor & $\begin{array}{l}\text { Jumlah/Indikat } \\
\text { or }\end{array}$ \\
\hline \multirow{4}{*}{1} & \multirow{4}{*}{ Pertama } & \multirow{4}{*}{$\begin{array}{l}\text { Menerjemahkan } \\
\text { (translation) }\end{array}$} & 1 & 5 & \multirow{4}{*}{25} \\
\hline & & & 2 & 5 & \\
\hline & & & 3 & 5 & \\
\hline & & & 5 & 10 & \\
\hline \multirow{3}{*}{2} & \multirow{3}{*}{ Kedua } & \multirow{3}{*}{$\begin{array}{l}\text { Menafsirkan } \\
\text { (interpretation) }\end{array}$} & 4 & 5 & \multirow{3}{*}{30} \\
\hline & & & 6 & 15 & \\
\hline & & & 8 & 10 & \\
\hline \multirow{4}{*}{3} & \multirow{3}{*}{ Ketiga } & \multirow{3}{*}{$\begin{array}{l}\text { Mengekstrapolasi } \\
\text { (extrapolation) }\end{array}$} & 7 & 15 & \multirow{3}{*}{45} \\
\hline & & & 9 & 15 & \\
\hline & & & 10 & 15 & \\
\hline & & Jumlah & & & 100 \\
\hline
\end{tabular}

Sumber: Daryanto, 2005: 106

b. Interview

Interviem merupakan cara mengumpulkan data dengan melakukan wawancara kepada para responden yang dianggap dapat memberikan data/informasi sehubungan dengan masalah yang sedang diteliti untuk melengkapi data. Dalam hal ini peneliti melakukan wawancara secara terstruktur kepada guru pendidikan matematika kelas XI-3 SMA Negeri 8 Banda Aceh, dan kepada 6 orang siswa sebagai sempel. Pengambilan sampel siswa dilakukan setelah melihat nilai/hasil tes pemahaman, yaitu siswa yang memiliki nilai rendah, sedang, dan tertinggi.

\section{c. Angket (kuesioner)}

Angket (kuesioner) merupakan suatu pengumpulan data dengan memberikan atau menyebarkan daftar pertanyaan/pertanyaan kepada responden dengan harapan 
memberikan respons atas daftar pertanyaan/pertanyaan tersebut. Daftar pertanyaan/pertanyaan dapat bersifat terbuka jika jawaban tidak ditentukan sebelumnya, sedangkan bersifat tertutup jika alternative jawaban telah disediakan.

Angket yang peneliti gunakan dalam pengumpulan data penelitian ini bersifat tertutup karena alternatif jawaban sudah disediakan (Oemar Hamalik,2002). Angket yang dimaksud dalam penelitian ini adalah angket respon siswa dalam mengguanakan alat peraga dalam proses pembelajaran matematika. Angket respon siswa berupa pertanyaan tertulis yang diajukan kepada siswa untuk mengetahui respon siswa terhadap pembelajaran matematika yang mennggunakan alat peraga. Angket respon siswa ini berisi pertanyaan tentang tanggapan siswa terhadap penggunaan alat pearag pada proses pembelajaran yang dilaksanakan. Angket yang diberikan diisi oleh setiap siswa yang mengikuti kegiatan pembelajaran.

Lembaran angket respon siswa berupa pertanyaan tertulis yang diajukan kepada siswa untuk mengetahui respon siswa terhadap penggunaan alat peraga dalam pembelajaran Pendidikan Pancasila dan Kewarganegaraan. Skala yang digunakan dalam menilai respon siswa adalah skla likert. Skala Likert digunakan untuk mengukur sikap, pendapat dan persepsi seseorang atau kelompok tentang sesuatu kejadian ( Riduwan, 2007 : 16). Setiap butir di sekor kemudian dijumlahkan untuk mendapatkan persentase respon siswa terhadap pembelajaran Pendidikan. Pancasila dan kewarganegaraan dengan menggunakan alat peraga

Tabel 2. Pedoman Skor Angket Responden Siswa

\begin{tabular}{|l|l|l|l|l|l|}
\hline \multirow{2}{*}{ Penyataan } & \multicolumn{3}{|l|}{ Sekor Jawaban } \\
\cline { 2 - 6 } & $\begin{array}{l}\text { Sangat } \\
\text { Setuju (SS) }\end{array}$ & Setuju (S) & $\begin{array}{l}\text { Kurang } \\
\text { Setuju (KS) }\end{array}$ & $\begin{array}{l}\text { Tidak Setuju } \\
\text { (TS) }\end{array}$ & $\begin{array}{l}\text { Sangat } \\
\text { Tidak Setuju } \\
\text { (STS) }\end{array}$ \\
\hline $\mathbf{( + )}$ & $\mathbf{5}$ & $\mathbf{4}$ & $\mathbf{3}$ & $\mathbf{2}$ & $\mathbf{1}$ \\
\hline $\mathbf{( - )}$ & $\mathbf{1}$ & $\mathbf{2}$ & $\mathbf{3}$ & $\mathbf{4}$ & $\mathbf{5}$ \\
\hline
\end{tabular}

\section{Uji Coba Tes/Soal}

Instrumen yang baik merupakan instrumen yang memenuhi syarat validitas dan reliabelitas. Uji coba instrument inresponden sebenarnya. Responden untuk uji coba i menggunakan responden yang ada di luar response sebenarnya. Responden untuk uji coba 
respoden tes adalah kelas XI-4 SMA negeri 8 Banda Aceh yang dianggap telah lebi dahulu mempelajari materi PPKn.

1. Uji Validitas

Validitas adalah suatu ukuran yang menunjukkan tingkat-tingkat kevalidan atau kesahihan sesuatu intrumen. Suatu instrument dikatakan sahih apabila telah memenuhi validitas yang telah ditentukan. Untuk mengukur validitas soal sebagai instrument menggunakan rumus pearson product moment dengan perhitungannya bantuan computer program Microsoft Excel 2010. Semua butir pertanyaan dikatakan valid atau sahih apabila mempunyai $r_{\text {hitung }} \geq r_{\text {tabel }}$ dengan taraf signifikan $5 \%$ atau 0,05 .

\section{Uji Reliabilitas}

Reabilitas dapat menunjukkan bahwa suatu instrument dapat dipercaya untuk digunakan sebagai alat pengumpul data karena instrument tersebut sudah baik. Untuk menguji reliabilitas digunakan uji reliabilitas internal yang diperoleh dengan cra menganalisis data dari satu kali hasil pengetasan, kemudian data ayang telah diperoleh dianalisis menggunakan teknik pengujian menggunakan rumus Alpha Cronbach, dengan rumus sebagai berikut:

$$
r_{1}=\left(\frac{h}{k-1}\right)\left(1-\frac{\sum v_{D^{2}}}{u_{L^{2}}}\right)
$$

Keterangan:

$r_{1} \quad=$ reliabilitas instrument

$\mathrm{K} \quad$ = banyaknya butir pertanyaan atau banyaknya soal

$\sum \sigma_{D^{2}}=$ jumlah varians butir

$\sigma_{t^{2}} \quad=$ varians total

\section{Hasil uji Coba Instrumen}

Uji coba instrument dilakukan pada siswa kelas XI-3 SMA Negeri 8 Banda Aceh. Untuk menguji apakag instrument memenuhi persyaratan sebagai alat pengumpulan data, maka di tempuh langkah-langkah sebagai berikut:

a. Perhitungan Validitas Instrumen

Instrument tes terdiri dari 10 soal, selanjutnya dilakukan perhitungan dengan menggunakan rumus pearson dengan bantuan computer program Microsoft Excel 2010 disajikan dalam tabel berikut:

Jurnal Serambi Ilmu. p-ISSN 1693-4849, e-ISSN 2549-2306

Journal of Scientific Information and Educational Creativity 
Tabel .3 hasil Validitas Uji Coba Instrumen Tes

\begin{tabular}{|c|c|c|c|}
\hline No Item & $\mathrm{r}_{\text {tabel }}$ & $\mathrm{r}_{\text {hitung }}$ & Keteranagan \\
\hline 1 & 0,444 & 0,666491672 & valit \\
\hline 2 & 0,444 & 0,572427474 & valit \\
\hline 3 & 0,444 & 0,588404287 & valit \\
\hline 4 & 0,444 & 0,694097836 & valit \\
\hline 5 & 0,444 & 0,636043102 & valit \\
\hline 6 & 0,444 & 0,655040468 & balit \\
\hline 7 & 0,444 & 0,703126956 & valit \\
\hline 8 & 0,444 & 0,500171556 & valit \\
\hline 9 & 0,444 & 0,571901279 & valit \\
\hline 10 & 0,444 & 0,68621036 & valit \\
\hline
\end{tabular}

Sumber: data primer 2019

Hasil data uji coba tersebut dinyatakan sepuluh instrument valit, sehingga pengambilan data menggunakan 10 soal tersebut.

b. Perhitungan Reliabilitas Instrumen

Perhitungan reliabilitas menggunakan computer program Microsoft Excel menggunakan rumus alpha cronbach. Data yang telah dianalisis memperoleh tingkat reliabilitas dalam pemahaman siswa dapat dilihat pada tabel berikut:

Tabel 3.4 Hasil Reliabilitas Uji Coba Instrumen Tes

\begin{tabular}{|c|c|c|}
\hline Variabel & Nilai Alpha & Keterangan \\
\hline Pemahaman siswa & 0,779325 & Reliabel \\
\hline
\end{tabular}

Sumber: data primer 2019.

Hasil uji reliabilitas menunjukkan bahwa butir pertanyaan adalah reliabel karena mempunyai nilai cronbach alpha $>0,60$. Setelah dilakukan uji validitas dan reliabilitas instrument, maka diperoleh butir-butir soal yang valit dan reliabel.

\section{Teknik Analisis Data}

Setelah seluruh data terkumpul maka tahap selanjutnya adalah pengolahan data. Adapun data yang diolah dalam penelitian ini adalah data tes pemahaman siswa dan data respon siswa.

Jurnal Serambi Ilmu. p-ISSN 1693-4849, e-ISSN 2549-2306 
a. Data Tes Pemahaman Siswa

Untuk menganalisis pemahaman siswa, peneliti menggunakan analisis data persentase, yaitu: $\mathrm{p}=\frac{n}{N} \times 100 \%$, Keterangan: $\mathrm{p}=$ Persentase, $\mathrm{n}=$ Jumlah scor yang diperoleh, $\mathrm{N}=$ Jumlah scor maksimal (Arikunto: 2006)

Adapun penggolongan persentase secara kolaboratif data pemahaman siswa yang menyangkut Menerjemahkan (translation), Memnafsirkan (interprelation). Mengekstrapolasi (extrapolation), adalah: 90\%-100\%=Sangat Memahami, 70\%-89\% = Memahami, $60 \%-69 \%=$ Cukup Memahami, $50 \%-59 \%=$ Kurang Memahami, $0 \%-49 \%=$ Sangat kurang Memahami (Arikunto: 2006)

\section{b. Data Respon Siswa}

Data respon siswa diperoleh melalui aangket, dianalisis menggunakan statistic deskriptif dengan persentase. Menurut Zubaidah dan Kumar (Wahyuni,2007) "persentase dari setiap respon siswa diperoleh dengan membagi jumlahrespon siswa tiap aspek yang muncul dengan jumlah seluruh siswa dikali seratus persen:. Secara sistematis persentase dari setiap respon siswa dapat ditulis:

$$
\text { Persentase }(\%)=\frac{n}{N} \times 100 \%
$$

Menurut Suhardinsyah (2014) menyatakan bahwa Respon siswa dikatakan efektif jika jawaban siswa terhadap pertanyaan positif untuk tiap aspek yang direspon pada setiao komponen pembelajaran diperoleh persentase $\geq 70 \%$.

\section{HASIL PENELITIAN DAN PEMBAHASAN}

\section{a. Hasil Tes}

Berdasarkan hasil pemberian tes/soal, pemahaman siswa terhadap materi Pendidikan Pancasila dan Kewarganegaraan dengan menggunakan alat peraga yang diselesaikan oleh 40 orang siswa kelas XI-3 SMA Negeri 8 Banda Aceh, diperoleh nilai persentase pemahaman siswa terhadap materi Pendidikan Pancasila dan Kewarganegaraan dengan menggunakan alat peraga yang disajikan dalam grafik berikut ini:

Jurnal Serambi Ilmu. p-ISSN 1693-4849, e-ISSN 2549-2306 Journal of Scientific Information and Educational Creativity 


\section{Grafika 1. Persentase pemahaman siswa}

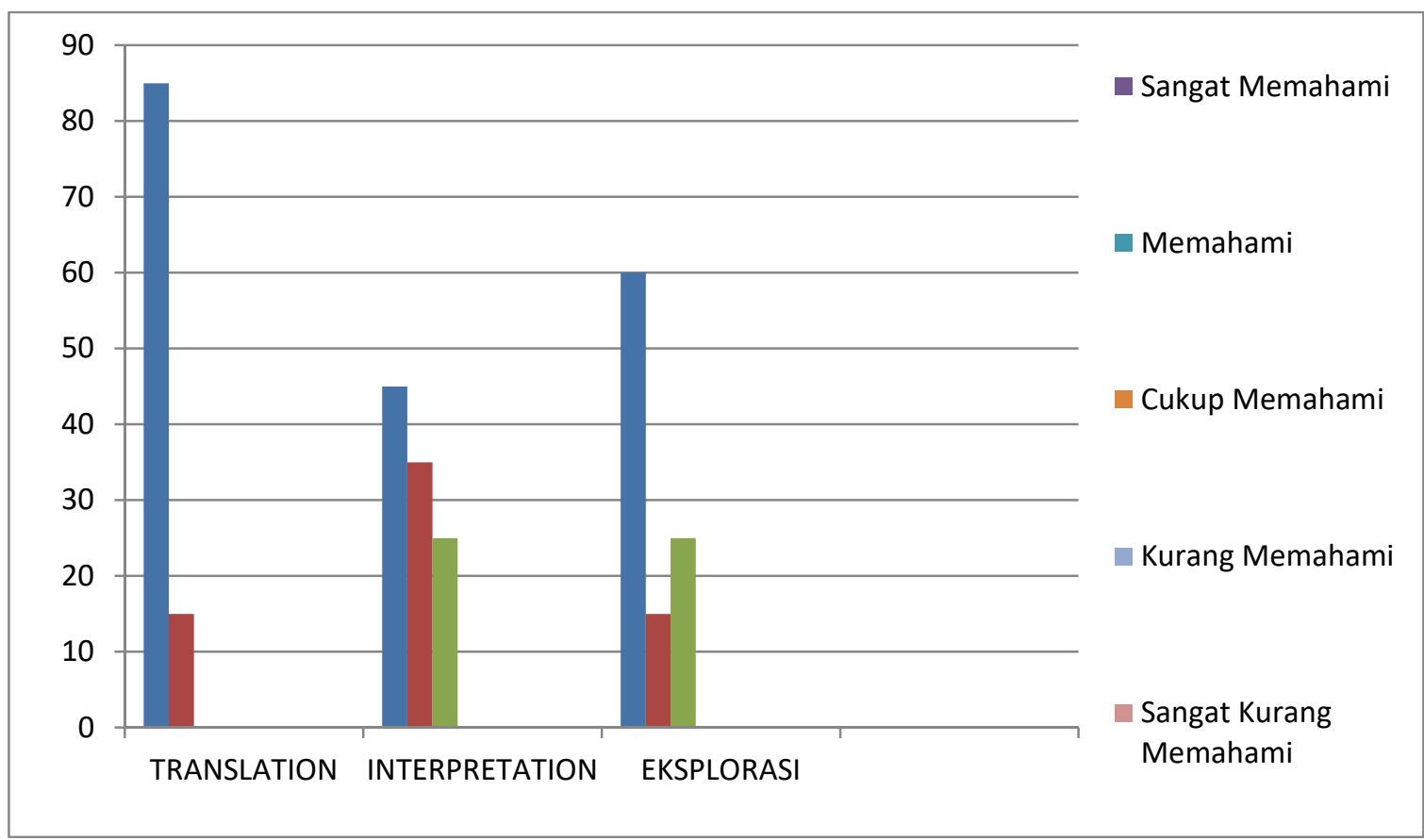

Sumber : data diolah

Dari grafik di atas terlihat bahwa indikator pemahaman siswa pada aspek menerjemahkan (translation) memiliki persentase 85\% pada kategori sangat memahami dan 15\% pada kategori memahami. Sedangkan pada kategori cukup memahami, kurang memahami, dan sangat kurang memahami tidak ada. Dari angka persentase pada indikator tersebut terlihat bahwa siswa kelas XI-3 SMA Negeri 8 Banda Aceh telah memahami konsep materi Pendidikan Pancasila dan Kewarganegaraan pada aspek menerjemahkan melalui alat peraga, berdasarkan wawancara dengan guru yang bersangkutan, hal ini dikarenakan guru Pendidikan Pancasila dan Kewarganegaraan selalu berupaya untuk menggunakan alat peraga kepada siswanya dalam proses belajar mengajar materi Pendidikan Pancasila dan Kewarganegaraan di sekolah.

Sedangkan untuk indikator pemahaman siswa pada aspek menafsirkan (interprestation) memiliki persentase $40 \%$ pada kategori sangat memahami, kemudian 35\% memahami serta $25 \%$ cukup memahami, dan tidak siswa pada kategori kurang memahami dan sangat kurang memahami. Dari angka persentase tersebut terlihat bahwa masih ada sebahagian siswa (5\%) yang masil kurang paham materi Pendidikan Pancasila dan Kewarganegaraan dengan 
menggunakan alat peraga, berdasarkan hasil wawancara dengan siswa yang bersangkutan ternyata yang menyebabkan mereka kurang memahami pada indikator tersebut yaitu dikarenakan mereka kurang memerhatikan/menyimak ketika guru menjelaskan materi Pendidikan Pancasila dan Kewarganegaraan dengan menggunakan alat peraga dalam proses pembelajaran, inilah yang menyebabkan mereka kurang memahami materi Pendidikan Pancasila dan Kewarganegaraan dengan penggunaan alat peraga pada aspek menafsirkan (interprestation) materi Pendidikan Pancasila dan Kewarganegaraan.

Persentase indikator pemahaman siswa pada aspek mengeksplorasi memiliki persentase $60 \%$ pada kategori sangat memahami dan $15 \%$ pada kategori memahami, kemudian $25 \%$ dan cukup memahami dan $0 \%$ kategori kurang memahami kemudian 0\% pada kategori sangat kurang memahami. Berdasarkan penggolongan persentase pemahaman siswa bahwa dikatakan siswa itu memahami apabila diperoleh persentase pemahaman $\geq 70 \%$. Persentase siswa kategori memahami dan sangat memahami diperoleh $100 \%$ pada aspek menerjemahkan (translation), 100\% menafsirkan (interpretation), dan untuk aspek mengeksplorasi $100 \%$.

Secara umum jika dilihat dari keseluruhan indikator pemahaman siswa dapat dikatakan bahwa tingkat pemahaman siswa terhadap materi Pendidikan Pancasila dan Kewarganegaraan dengan menggunakan alat peraga berada pada kategori memahami. Dimana data selengkapnya dapat dilihat pada tabel 4.

Tabel 4 Persentase keseluruhan Pemahaman Siswa

\begin{tabular}{|l|l|l|}
\hline Kategori & Jumlah Siswa & Persentase \% \\
\hline Sangat Paham & 14 & $35 \%$ \\
\hline Paham & 26 & $65,00 \%$ \\
\hline Cukup Paham & 0 & $0,00 \%$ \\
\hline Kurang Paham & 0 & $0,00 \%$ \\
\hline Sangat Kurang Paham & 0 & $0 \%$ \\
\hline Jumlah & 40 & $100 \%$ \\
\hline
\end{tabular}

Sumber: Hasil Analisa Data

\section{b. Hasil Lembar Angket Respon Siswa}

Angket respon siswa bertujuan untuk mengetahui perasaan siswa, minat siswa, dan pendapat siswa terhadap penggunaan alat peraga pada proses belajar Pendidikan Pancasila

Jurnal Serambi Ilmu. p-ISSN 1693-4849, e-ISSN 2549-2306 Journal of Scientific Information and Educational Creativity 
dan Kewarganegaraan. Hasil respopn siswa terhadap pengunaan alat peraga dalam proses pembelajaran Pendidikan Pancasila dan Kewarganegaraan dapat dilihat pada tabel di bawah ini.

Tabel 5 Persentase Respon Siswa

\begin{tabular}{|l|l|l|}
\hline Pilihan & Keterangan & Persentase (\%) \\
\hline SS & Sangat Setuju & $49 \%$ \\
\hline S & Setuju & $45 \%$ \\
\hline KS & Kurang Setuju & $6 \%$ \\
\hline TS & Tidak Setuju & $0 \%$ \\
\hline STS & Sangat Tidak Setuju & $0 \%$ \\
\hline Total & & $100 \%$ \\
\hline
\end{tabular}

Dari tabel diatas respon siswa yang paling banyak terdapat pada pilihan sangat setuju yaitu mencapai $49 \%$, kemudian untuk respon siswa pada pilihan setuju $45 \%$. Sedangkan untuk pilihan kurang setuju 6\%, tidk setuju 0\%, dan sangat tidak setuju 0\%. Resppon siswa dikatakan efektif apabila penilaian jawaban siswa terhadap pertanyaan positif pada setiap komponen pembelajaran diperoleh persentase $270 \%$. Berdasarkan tabel di atas dapat disimpulkan bahwa respon siswa terhadap masing-masing komponen berada pada pilihan setuju dan sangat setuju yaitu 94\%, sedangkan respon siswa terhadap masing-masing komponen pada pilihan kurang setuju 6\%, tidak setuju, dan sangat tidak setuju 0\%. Dengan demikian respon siswa terhadap penggunaan alat peraga pada proses belajak Pancasila dan Kewarganegaraan adalah positif.

\section{c. Interview/wawancara}

Interview guru dalam mengelola pembelajaran dengan menggunakan alat peraga pada proses belajar Pendidikan Pancasila dan Kewarganegaraan kelas XI-3 SMA Negeri 8 Banda Aceh. Berdasarkan hasil wawancara dengan guru yang bersangkutan, dengan mengelola pembelajaran dengan menggunakan alat peraga, dapat membuat siswa lebih mudah dalam menyerap pelajaran, dapat menambah prmahaman siswa, memudahkan siswa dalam menangkap materi dan dapat meningkatkan prestasi siswa. Namun untuk kendala yang dialami dalam pembelajaran dengan alat peraga menurut hasil wawancara dengan guru yang bersangkutan kendalanya jarang terjadi, paling keterbatasan waktu. Maka guru harus benarbenar mempersiapkan alat dan bahan sebelum pembelajaran dimulai.

Jurnal Serambi Ilmu. p-ISSN 1693-4849, e-ISSN 2549-2306 Journal of Scientific Information and Educational Creativity 
Wawancara siswa dapat dilihat pada lamiran 3d. berdasarkan hasil wawancara yang dilakukan kepada 6 orang siswa, mereka semua senang belajar Pancasila dan Kewarganegaraan dengan menggunakan alat peraga, karena dengan menggunakan alat peraga dapat membuat mereka lebih mudah memahami pelajaran, membuat mereka lebih aktif dan membuat suasana belajar nyaman. Namun tidak keseluruhan siswa dapat memahami semua yang diajarkan oleh guru. Adanya sebahagian suswa yang memahami kesulitan tersebut dikarenakan mereka kurang menyimak ketika guru menjelaskan, atau bercerita dengan temannya ketika guru sedang menjelaskan. Hal ini yang menyebabkan mereka mengalami kesulitan ketika menyelesaikan tugas yang diberikan guru, yaitu mereka mengalami kesulitan ketika mengubah soal cerita ke bentuk kalimat pelajaran Pancasila dan Kewarganegaraan.

\section{Pembahasan}

Pada bagian ini diuraikan pembahasan hasil dari penelitian secara keseluruhan. Analisis data tes pemahaman siswa terhadap materi dengan menggunakan alat peraga pada proses pembelajaran Pendidikan Pancasila dan Kewarganegaraan dikelas XI SMA Negeri 8 Banda Aceh. Hasil analisis data tes pemahaman siswa menunjukan bahwa tingkat pemahaman siswa berada pada kategori memahami di indikator memahami (transaltion), menafsirkan (interpretation), dan mengekplorasi. Dimana siswa yang berada pada kategori memahami dan sangat memahami mencapai $100 \%$ pada indikator menerjemahkan (translation), 100\% menafsirkan (interpretation), dan untuk aspek mengeksplorasi 100\%.

Berdasarkan penggolongan persentase secara kolaboratif data indikator pemahaman siswa yang menyangkut menerjemahkan (translation), menafsirkan (interpretation), dan mengeksplorasi, siswa dikatakan memahami apabila diperoleh persentase pemahaman $\geq 70 \%$.

Dengan demikian berdasarkan penggolongan persentase pemahaman siswa di atas terlihat bahwa tingkat pemahaman siswa terhadap materi Pendidikan Pancasila dan Kewarganegaraan dengan menggunakan alat peraga dalam proses pembelajaran memiliki persentase tertinggi pada indikator menerjemahkan (translation) yaitu mencapai $100 \%$ dengan kategori indikator mengeksplorasi $100 \%$ dengan kategori memahami.

Secara umum jika dilihat dari keseluruhan indikator pemahaman siswa terdapat 14 orang siswa 35\% berada pada kategori sangat memahami, 26 siswa $65 \%$ berada pada kategori

Jurnal Serambi Ilmu. p-ISSN 1693-4849, e-ISSN 2549-2306 Journal of Scientific Information and Educational Creativity 
memahami. Dengan demikian berdasarkan uraian di atas dari ketiga indikator pemahaman siswa yang di isi oleh 40 siswa kelas XI-3 SMA Negeri 8 Banda Aceh dalam memahami meteri Pendidikan Pancasila dan Kewarganegaraan dengan menggunakan alat peraga berada pada kategori memahami yaitu indikator menafsirkan (interpretation) dan mengeksplorasi dan sangat memahami pada indikator menerjemahkan (translation). Dimana indikator menerjemahkan (mengeksplorasi) memiliki persentase tertinggi yaitu 100\% pada kategori memahami dan sangat memahami. Sedangkan indikator menafsirkan dan mengeksplorasi berada pada kategori memahami. Namun dilihat dari rata-rata keseluruhan indikator pemahaman siswa secara umum dapat dikatakan tingkat pemahaman siswa berada pada kategori memahami. Ketercapaian indikator pemahaman siswa dalam memahami materi Pendidikan Pancasila dan Kewarganegaraan dengan menggunakan alat peraga berada pada kategori memahami ini karena tidak luput dari peran guru yang memang sudah berpengalaman dalam mengajar menggunakan alat peraga, dimana guru tersebut menciptakan suasana belajar lebih aktif dan menyenangkan. Guru juga selalu berusaha memberikan pengenalan tentang materi Pendidikan Pancasila dan Kewarganegaraan dengan alat peraga kepada siswa, misalnya lewat poster-poster yang bergambarkan alat peraga yang ditempelkan diruang kelas atau lewat mading.

Kemudian berdasarkan hasil interview yang dilakukan kepada guru Pendidikan Pancasila dan Kewarganegaraan yang bersangkutan memang pembelajaran dengan menggunakan alat peraga dapat mempermudah siswa dalam memahami pelajaran, siswa lebih cepat menangkap materi, pembelajaran dengan menggunakan alat peraga juga membuat siswa lebih aktif, kesuksesan pembelajaran juga dikarenakan didukung oleh pengalaman guru yang sudah lebh dari 20 tahun dalam mengajar di SMA tersebut, dan didukung oleh fasilitas di sekolah bisa dikatakan memadai, walau belum pada kategori sangat memadai. Fasilitas yang dimiliki sekolah yang mendukung pembelajaran diantaranya buku paket, perpustakaan, gedung sekolah, laboratirium, berbagai media dan alat peraga.

Kemudian dari hasil interview kepada siswa, dikatakan mereka memang sering belajar dengan menggunakan alat peraga, bahwa ketika masih sekolah dasarpun mereka sering belajar dengan menggunakan alat peraga, karena belajar dengan menggunakan alat peraga menyenangkan, mereka lebih aktif, dalam memahami pelajaran mereka lebih mudah. Mereka juga mengakui terkadang tidak semua yang diberikan oleh guru bisa dipahami semua, dikarenakan mereka kurang memerhatikan ketika guru menjelaskan, kurang hati-hati 
ketika menyelesaikan tugas, dan bahkan ada siswa yang asik bercerita atau bermain, sehingga hal-hal yang seperti inilah yang membuat siswa masih ada yang kurang memahami materi dengan menggunakan alat peraga.

Berdasarkan hasil angket rspon siswa diperoleh bahwa respon siswa terhadap pembelajaran dengan menggunakan alat peraga mencapai persentase $94 \%$ setuju atau sangat setuju. Sehingga, secara umum pembelajaran Pendidikan Pancasila dan Kewarganegaraan dengan menggunakan alat peraga mendapat respon baik dari siswa. Hal ini dikarenakan belajar dengan menggunakan alat peraga membuat mereka tidak cepat bosan, mudah dipahami, dan membuat mereka lebih aktif. Keaktifan siswa terlihat ketika peneliti mengganti siswa saat mengisi soal yang diberikan.

\section{KESIMPULAN}

Setelah menganalisis dan membahas hasil penelitian yang berkenaan dengan analisis pemahaman siswa terhadap materi Pendidikan Pancasila dan Kewarganegaraan dengan menggunakan alat peraga pada proses pembelajar Pendidikan Pancasila dan Kewarganegaraan di kelas XI-3 SMA Negeri 8 Banda Aceh dapat ditarik beberapa kesimpulan diantaranya sebagai berikut:

1. Tingkat pemahaman siswa terhadap materi Pendidikan Pancasila dan Kewarganegaraan dengan menggunakan alat peraga pada proses belajar Pendidikan Pancasila dan Kewarganegaraan berada pada kategori memahami, pada tiga indikator pemahaman siswa yaitu menerjemahkan (translation) 100\% menafsirkan (interpretation) 75\% mengeksplorasi $70 \%$.

2. Respon siswa teradap penggunaan alat peraga pada proses belajar Pendidikan Pancasila dan Kewarganegaraan adalah positif dengan persentase $94 \%$.

3. Berdasarkan penelitian tersebut menunjukkan bahwa dalam kegiatan belajar mengajar Pendidikan Pancasila dan Kewarganegaraan menggunakan alat peraga, mengembangkan berbagai aktivitas dan kreatifitas siswa dalam pembelajaran. Disamping guru menguasai materi juga wajib menguasai tentang alat peraga yang digunakan

\section{DAFTAR PUSTAKA}

- A. Samana, Sistem Pengajaran, Yogyakarta: Kanisius, 2001 
- Abdurrahman, M. 2009. Pendidikan Bagi Anak Berkesulitan Belajar. Jakarta: Rineka Cipta.

- Anita, Sri. (2008). Strategi Pembelajaran di SD. Jakarta: Universitas Terbuka.

- Anni. 2004. Pendidikan Bagi Anak Kesulitan Belajar. Jakarta: Reneka Cipta.

- Arikunto, S. (2002). Prosedur Penelitian Suatu Pendekatan Praktik. Jakarta: Rineka Cipta.

- Arikunto, S. (2002). Prosedur Penelitian Suatu Pendekatan Praktik (edisi revisi VI). Jakarta: Rineka Cipta.

- Azhar Arsyad, Media Pengajaran, Jakarta: PT. Raja Grafindo Persada, 1997.

- Bahri, Saiful, dan Zain, Aswan. (2002). Strategi Belajar Mengajar. Jakarta: Bhineka Cipta.

- Bogdan dan Biklen. (1992). Qualiytative Research for Education. Boston, MA: Allyn and Bacon.

- BSNP. (2008). Paduan Penyusunan Kurikulum Tingkat Satuan Pendidikan Jenjang Pendidikan Dasar dan Menengah. Jakarta: Depdiknas.

- Daryanto. (2005). Evaluasi Pendidikan. Jakarta: Rineka Cipta.

- Djamarah, B. S. 2008. Psikologi Belajar. Jakarta: Rineka Cipta.

- Depdikbud. Kamus Besar Bahasa Indonesia. Jakarta: Balai Pustaka.

- Enco, M. 2004. Implementasi Kurikulum 2004. Bandung: Remaja Rosdakarya.

- Hafnida. 2012. "Upaya Peningkatan Hasil Belajar dan Aktivitas Siswa Melalui Pendekatan Kontekstual pada Materi Pokok Ekosistem di Kelas X SMA Swasta Dharma Patra P. Berandan Tahun Pembelajaran 2011 / 2012". Skripsi. Universitas Negeri Medan, Medan.

- Hamalik, Omar. (2011). Kurikulum dan Pembelajaran. Jakarta: Bumi Aksara.

- Jufrianda. (2015). Penggunaan Alat Peraga Dalam Pembelajaran Pendidikan Pancasila dan Kewarganegaraan SMP. Skripsi Aceh Besar : Universitas Abulyatama Aceh.

- Kunandar. 2008. Guru Profesional, Implementasi Kurikulum Tingkat Satuan Pendidikan (KTSP) dan Sukses dalam Sertifikasi Guru. Jakarta: PT Raja Grafindo Persada.

Jurnal Serambi Ilmu. p-ISSN 1693-4849, e-ISSN 2549-2306 Journal of Scientific Information and Educational Creativity 
- Kuswadi. 2011. "Menjadi Guru Profesional Menciptakan Pembelajaran Kreatif dan Menyenangkan Menurut Dr. E. Mulyasa, M.Pd". Skripsi. Fakultas Tarbiyah Institut Agama Islam Negeri Walisongo, Semarang.

- Perwanto, Ngalim. (2013). Prinsip-prinsip dan Teknik Evaluasi Pengajaran. Bandung: Remaja Rodakarya.

- Retniningsih, Ana. Dan Suharso. (2005). Kamus Besar Bahasa Indonesia. Semarang: CV.Widya Karya.

- Salim, Peter dan Yenny Salim. (2002). Kamus Besar Bahasa Indonesia Komtemporer. Jakarta: Modern English Press.

- Sardiman. (2011). Interaksi dan Motivasi Belajar Mengajar. Jakarta: Rajawali Press.

- Setyowati, R. W. 2013. "Penggunaan Modul Biologi Berbasis Inkuiri Terbimbing pada Materi Pokok Ekosistem Semester Dua Kelas X SMA/MA”. Skripsi. Fakultas Sains dan Teknologi Universitas Islam Negeri Sunan Kalijaga, Yogyakarta.

- Sudiono, Anas. (2009). Pengantar Evaluasi Pendidikan. Jakarta: Raja Grafinda.

- Sudjana, Nana. (2012). Penilaian Hasil Proses Belajar Mengajar. Bandung: Remaja Rosda Karya.

- Sugiyono, 2010. Metode Penelitian Kuantitatif dan R\&D. Bandung : ALFABET

- Suhardinsyah, Said. (2014). Penerapan Model Kooperatif Tipe STAD Pada Materi Persamaan Garis Lurus Di Kelas VIII SMP PKPU. Banda Aceh: Skripsi Universitas Syiah Kuala Fakultas Keguruan dan Ilmu Pendidikan, tidak diterbitkan.

- Suherman, Erman. (2001). Strategi Pembelajaran matematiaka Kontenporer. Bandung: JICA.

- Sukayati. (2003). Media Pembelajaran Sekolah Dasar. Yogyakarta: PPPG Matematika Pendidikan Pancasila dan Kewarganegaraan.

- Sudaryono, (2012). Dasar-dasar Evaluasi Pembelajaran. Yogyakarta: Graha Ilmu.

- Sudijono, Anas. (2004). Pengantar Evaluasi Pembelajaran. Jakarta: Rajawali Pers.

- Suryabrata, S. 2012. Psikologi Pendidikan. Jakarta: Rajawali Pers

- Tamarli, T. and Akhyar, A., 2018. Penerapan Model Pembelajaran Student Facilitator And Explaining (Sfe) Dalam Meningkatkan Kemampuan Berpikir Kreatif Siswa Pada

Jurnal Serambi Ilmu. p-ISSN 1693-4849, e-ISSN 2549-2306

Journal of Scientific Information and Educational Creativity 
Materi Sistem Hukum Dan Peradilan Di Indonesia. JURNAL SERAMBI ILMU, 30(1), pp.46-50.

- Ustman, Uzer. (2000). Upaya Optimalisasi Kegiatan Belajar Mengajar. Bandung: PT Remaja Rosda Karya.

- Wahyuni,2007. Perbandingan Hasil Belajar Pendidikan PPKn Dengan Menggunakan Alat Peraga dan Tidak Menggunakan Alat Peraga ( Kuasi Eksperimen di SMP Negeri 6 Banda Aceh) Skripsi. Fakultas Keguruan dan Ilmu Pendidikan Universitas Abulyatama.

- Winkel. 2004. Psikologi Pembelajaran. Jakarta: Grasindo. 